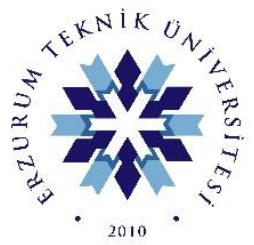

\title{
İLAHİ KOMEDYA VE MI'RAÇNÂMELERDE CENNET TASAVVURUNUN KARŞILAŞTIRILMASI
}

\section{COMPARING THE IMAGINATION OF HEAVEN BETWEEN DIVINE} COMEDY AND THE MI'RÂÇNÂMES

\section{AYŞE ÇELEBIOĞLU}

Dr. Öğr. Üyesi, Artvin Çoruh Üniversitesi, Fen-Edebiyat Fakültesi, Türk Dili ve Edebiyatı Bölümü aysecele@artvin.edu.tr

(iD) https://orcid.org/0000-0002-2870-1162

ETÜ Sosyal Bilimler Enstitüsü Dergisi |ETU Journal of Social Sciences Institute

S.9, Ekim | October 2019, Erzurum

ISSN: 2149-939X

$\begin{aligned} \text { Makale Türü | Article Types } & : \text { Araştırma Makalesi | Research Article } \\ \text { Geliş Tarihi | Received Date } & : 16.07 .2019 \\ \text { Kabul Tarihi | Accepted Date } & : 06.09 .2019 \\ \text { Sayfa | Pages } & : \text { 67-88 } \\ \text { doi } & : \text { http://dx.doi.org/10.29157/etusbe.122 }\end{aligned}$

www.etusbe.com

https://dergipark.org.trletusbed

This article was checked by

$\boldsymbol{v}$ iThenticate" 



\title{
İLAHI KOMEDYA VE MI'RAÇNÂMELERDE CENNET TASAVVURUNUN KARŞILAŞTIRILMASI*
}

\author{
Ayşe ÇELEBİĞ̆LU
}

ETÜ Sosyal Bilimler Enstitüsü Dergisi (ETÜSBED), S.9, Ekim 2019, Sayfa: 67-88

\begin{abstract}
ÖZ
Batı Hümanizminin kurucularından olan ve kendisi de sağlam bir din eğitimi almış olan Dante, İlahi Komedya'nın Cehennem, Araf ve Cennet bölümlerinin tamamında teoloji bilgisininin derinliğini ve aynı zamanda Yunan mitolojisine ait bilgilerini en ince ayrıntısına kadar dizelerine yerleştirmiştir. Belki de bu yüzden eseri okuyanlar konuların ne kadar tanıdık geldiğinden bahseder. Bilhassa Cennet bölümünde hem Eski Ahit, hem İncil hem de Kur'an'da tasavvur edilen mekânlar karşımıza çıkar. Cehennem bölümünde yer altına inen Dante'nin yolculuğu Araf'tan itibaren yukarıya doğru devam eder. Cennet'te ise Batlamyus'un (Klaudyos Ptolemaios, M.S 85-165) gezegenler ve burçlarla ilgili olarak ortaya sürdüğü teori doğrultusunda, gezegenlerin diziliş sırasına göre Arş-1 alâya kadar yükselmiştir. İsrailiyatın etkisinin bariz şekilde görüldüğü Klasik Türk Edebiyatındaki müstakil mi'râçnâmeler ve bazı mesnevilerin mi'râciye bölümlerinde de şairlerimiz Hz. Muhammed'in mi'râca çıkarken aynı sıralama ile çıktı̆̆ını yazarlar. İspanyol oryantalist Miguel Asin Palacios Dante'nin Cennet bölümünü yazarken İbn Arabî́den çok fazla etkilendiğini hatta birçok konuda doğrudan alıntı yaptığını iddia etmektedir. Mi'râçnâme'leri ve İlahî Komedya'yı incelediğimizde İbn Arabî́nin, bilhassa gökyüzü ve cennet tasavvurlarının eserlere yansımasını büyük oranda görebiliriz. Ancak bu etkilerin yanı sıra mi'râç hadisesi ve Dante'nin metafizik yolculuğunun dinî birer eylem olmaları nedeniyle, Tevrat, İncil ve Kur'an'ın etkilerinin eserlere yansıması kaçınılmazdır. Bu çalışmada İlahi Komedya ve genel olarak mi'râciyelerin ortak ve farklı yönleri ile onları buluşturan İbn Arabî́nin ve Batlamyus'un teorilerinin karşılaştırmalı olarak incelenmesi yapılmıştır.
\end{abstract}

Anahtar Kelimeler: Dante, İlâhî komedya, İbn-i Arabî, Batlamyus, Palacios, Cennet, Miraç-nâme.

* ICOSTURK 2017, The 2nd International Conference On Studies In Turkology, (August 11-13 /Rome-Italy)'da sunulan bildiriye bazı ekleme ve çıkarmalar yapılarak yeniden düzenlenmiştir. 


\title{
COMPARING THE IMAGINATION OF HEAVEN BETWEEN DIVINE COMEDY AND THE MI'RÂÇNÂMES
}

\begin{abstract}
Being among the founders of Western Humanism, and a solid religious education of his own, Dante placed the knowledge the depths of theology and knowledge of Greek mythology in the depths of the Hell, Purgatory and Paradise sections of the Divine Comedy with full details in the lines. Maybe this is why the readers of the masterpiece mention how familiar topics are. In each of three parts of the work, as well as topics inspired from the Greek mythology, we encounter spaces imaged both in the Old Testament, Bible and Koran especially in the Paradise part. In part of Inferno, the journey of Dante who descends towards underground moves to upwards from limbo; whereas in Paradise, he ascends till the Throne of God based on the order of planets and the signs of zodiac put forward in accordance with the theory suggested by Ptolemy (Claudios Ptolemaios, A.D.85-165). On the other hand, our poets also narrated in the miraçnâmes and miraciye parts of several Mesnevis based in the Classical Turkish Literature which is obviously effected by İsrailiyat that the prophet Mohammed ascended to the miraj in the same order. The Spanish Orientalist Miguel Asin Palacios claims that Dante was influenced deeply by İbn-i Arabî while writing the part of Paradise, and he even quoted him directly for many topics. When we analyze the Miraç-nâmes and Divine Comedy, we can witness considerably the reflections of İbn-î Arabî's sky and heaven imaginations particularly on the masterpieces. However, aside from these influences, because the occasion of the prophet's ascension and Dante's metaphysical journey are religious acts, the reflections of effects of Torah, Bible and Koran on the works are inevitable. In this study, a comparative analysis was made for the common and different aspects of Divine Comedy and the miraciyes in general, as well as the theories by İbn-i Arabî and Ptolemy, both of whom served as sources to the former works.
\end{abstract}

Keywords: Dante, Divine Comedy, İbn-i Arabî, Ptolemy, Palacios, Heaven, Miraçnâme. 


\section{Giriş}

İlk insan Adem cennette yaratıldı ve ona eş olarak Havva yaratıldı. Sonra her ikisi de yaratıcının onlara koyduğu yasağı çiğnedikleri için dünyaya sürgüne gönderildiler. Bu trajedi Kur'an'da; “Fakat şeytan, ikisinin (ayağını) oradan kaydırdı. Böylece ikisini de içinde oldukları şeyden (ni'metten) çıkardı. Ve: "Birbirinize düşman olarak (dünyaya) inin. Sizin için (belli) bir zamana kadar yeryüzünde oturma ve faydalanma (geçimini temin etme) vardır." dedik." (Kur'an1 Kerim 2:36) şeklinde ifade edilir. Nitekim ayetten de anlaşılacağı üzere yukarıdan aşağıya doğru bir iniş/atılış söz konusudur. Bu nedenledir ki cennet hep gökyüzünde tasavvur edilmiştir. İnsan sürgün edildiği cennete/ilk zamana bir gün dönecek olmanın hayali ile yeryüzünde yaşamaya başlamıştır.

Gökyüzüne doğru yapılan astral yolculuklar, tarih boyunca bütün dinlerde ve tarihi kişiliklerde karşımıza çıkan önemli metafizik olaylardan biridir. Seçilmiş insanların, kralların ve peygamberlerin diğer insanlardan daha üstün varlıklar olduklarını kanıtlamalarının en önemli aşaması, gökyüzüne doğru yükselmeleridir. Bu yükselme bazen beden ve ruh ile bir binek aracılığıyla bazen sadece ruh ile bazen de rüyada yapılmıştır. Nitekim yazılı olarak günümüze ulaşmış bazı eserlerden öğrendiğimiz kadarıyla; Budha'dan İskender'e bazı peygamberlerden ermiş olarak kabul edilen kişilere kadar birçok dinî ve tarihî şahsiyet ruh veya beden ile yükselerek bir tür astral yolculuk yaptıklarını iddia etmişlerdir.

Çalışmamıza esas teşkil eden yolculuklar ise Hz. Muhammed'in ve Dante'nin yapmış oldukları yolculukların karşılaştırmasıdır. Eserlere konu olan birinci yolculuk, İslâm Peygamberi Hz. Muhammed'in Kur'an-1 Kerim'de de ayetlerde belirtildiği şekilde bir gece yolculuğu yaptığı ve bu yolculukta kendisine bazı ayetlerin apaçık gösterildiği, namazın Müslümân'lara bu yolculukta farz kılındığı ve benzer hadiselerin yaşandığı anlatılmaktadır (Kur'an-1 Kerim 17:1). Dante'nin yolculuğu ise uykusunda gittiğini iddia ettiği yerler ve oralarda gördüğü olayları içine alan tamamen kişisel bir deneyimi yazdığı ilâhî Komedya'nın "Cennet" bölümüdür.

$\mathrm{Bu}$ çalışmada amaç bir peygamberle bir yazarın astral yolculuğunu karşılaştırmak değil, Hz. Muhammed'in mi'râcını anlatan edebî metinlerle Dante'nin metafizik yolculuğunu anlattığı İlâhî Komedya adlı eserindeki ortak motifleri ve farklılıkları tespit etmek ve İspanyol akademisyen Palacios'un Dante ile ilgili iddialarının gerçeğe ne kadar uygun olduğunu incelemektir.

Cehennem, Araf ve Cennet başlıkları altında üç bölümden oluşan İlahi Komedya'nın son bölümünü, Dante, bir tür yükseliş olan Cennet yolculuğuna ayırmıştır. Cehennemde günahkârları ve çekilen azapları görüp arkasından Araf'ta yedi kat çıkan ve çıktı̆̆ı her katta yedi ölümcül günahtan sırasıyla arınan Dante, en saf ve günahsız haliyle Cennet'e ulaşır. Toplamda yedi gün süren bu metafizik 
yolculuk 7 Nisan 1300 perşembeyi Kutsal Cuma'ya ${ }^{1}$ bağlayan gece Cehennem ile başlamış, 14 Nisan 1300 sabahı Paskalya Perşembesi, Cennetin birinci katından başlayıp arş-1 âlâya kadar sürmüştür. Yolculuk, Cennet'in onuncu katında aynı gün son bulmuştur.

İlahî komedya'nın ilk iki bölümünde; ustam diye hitap ettiği ve hayranlığını hiçbir zaman saklamadığı Latin ozan Vergilius'un kılavuzluğunda tamamlayan Dante, Araf'ın son katında ölümsüz aşkı Beatrice ile karşılaşır. Genç yaşta ölen Beatrice, Dante'nin cennetteki yolculuğuna rehberlik edecektir. Pagan olarak ölmüş olmasından dolayı, Vergilius'un cennete girmesi yasaktır ancak bu yasağı, Dante, bu sefer de onun şiiriyle destanlaşan Trova'lı kahraman Aeneas ile delmiştir. Altıncı kantodan itibaren esere dâhil olan Aeneas'ın Roma' nın kurucusu olduğuna inanılır. ${ }^{2}$

Araştırmamıza konu olan miraciye türü eserler ise, Klasik Türk Edebiyatında, ilk olarak Ahmet Yesevînin Hikmetler adlı kitabının sonlarına doğru karşımıza çıkmaktadır. Mi'râc hadisesi hakkında Kur'an'da çok az bilgi verilmiştir. Olayın detaylarını daha çok hadislerden öğreniyoruz. İslâm dünyasında kaleme alınan ilk mir'âciyelerde anlatımın daha yalın olduğu ve konu ile ilgili ayetler ve hadislerin dışına pek çıkılmadığı görülmektedir. Ancak daha sonra yazılan mi'râcileyelerde dil farklılaşmaya, işe astronomi bilgileri, mucizeler ve peygamber kıssaları karışmaya başlamıştır. Yunan mitlerinde olduğu gibi gezegenler kişileştirilerek kendilerine çeşitli özellikler atfedilmiştir. Bu özellikler de yine mi'râciyelerde karşımıza çıkmakta ve şairlerin mısralarına ayrı bir güzellik ve sembolik bir anlam katmaktadırlar.

Divânlarda kaside nazım şekliyle, genelde dinî şiirlerin olduğu ilk bölümlerde yer alan mi'râciyeler, müstakil mesnevî şeklinde yazıldı̆̆ı gibi mesnevîlerin içerisinde bir bölüm olarak da yer almıştır.

Karşılaştırmaya başlamadan önce hadis kitaplarında anlatıldığı şekliyle mi'râç hadisesinin nasıl olduğundan bahsedersek daha sonra edebî bir tür olarak ne tür değişimlerle karşımıza çıktığını daha iyi değerlendirebiliriz.

Mi'râç hadisesininin özünde, Recep ayının 27 inci gecesi Hz. Muhammed amcasının kızının evinde yatarken Cebrail gelerek ona Allah'ın davetini vermesi ve onu gece yolculuğuna hazırlayıp çıkarması yatmaktadır. Burak'ın binit olarak geldiğinden bahsedilen bu yolculuk, Mescid-i Haram'dan Mescid-i Aksa'ya doğru yapılmıştır.

1 Kutsal Cuma dünya genelindeki Hristiyanların Hz. İsâ'nın çarmıha gerilmesi ve Golgotha'da ölüşünü andıkları dini gündür. Hayırlı Cuma, Büyük Cuma ve Paskalya Cuması diye de adlandırılır. www.vikipedia.org. (Erişim Tarihi: 09.09.2019)

2 Aeneas, Kral Ankhises ile Aphrodite'nin oğlu ve Troia kahramanlarından biridir. Latin şair Vergilius'un Aeneis isimli şaheserinin konusu olmuştur. Bu Anadolulu prens, Roma'nın milli kahramanı ve imparator Augustus'un atası sayıldı. Troya'nın yıkılmasından sonra Roma'ya giderek orayı yeniden inşa etti. 
Bazı hadislerde de Burak ile gökyüzüne çıktı̆̆ından bahsedilmektedir. ${ }^{3}$

Menziller konusu Mi'râciyelerin ve İlahî Komedya'nın en önemli bölümüdür. Çünkü cennet yukarıya doğru belli bir sıra ile çıkılan katlardan oluşmuş bir mekândır. Yolculuğun bu kısmının detaylarını da yine hadislerden öğreniyoruz. Sahih hadis kitaplarında benzer şekilde anlatılan bu yolculuğu özet olarak Akar'ın, Buhari'den alıntıladığı şekliyle vermek yeterli olacaktır. Merdivenle Kudüs'ten Cebrâîl ile birlikte gökyüzüne çıkan Hz. Muhammed birinci göğe çıkışlarını şu şekilde anlatmıştır:

"Nihâyet dünyâ semâsina vardı. Cibrîl gök kapısinı çaldı. (Hazin, bekçi melek tarafindan):

- Kim o? Denildi. Cibrîl:

- Cibrîl'im! Dedi. (Hâzin tarafindan):

- Yanindaki kimdir? Diye soruldu. Cibrîl:

- Muhammed! Diye cevap verdi. (Hâzin tarafindan):

Cibrîl:

Ya (göğe çıkmak için) ona (vahiy ve mi'râc dâveti) gönderildi mi? Diye soruldu.

- $\quad$ Evet gönderildi! Diye tasdik etti. (Hâzin tarafindan):

- Merhâba gelen zâta! Bu gelen kişi ne güzel yolcu? Denildi. Ve hemen gök kapısı açıldı. Ben birinci semâya varınca orada Âdem (peygamber)le karşılaştım. (Buhârî, Bedü'1halk, 6 nolu hadisten aktaran (Akar, 1980: 16).

$\mathrm{Bu}$ karşılama töreni yedi kat boyunca tekrarlanır, ancak her katta farklı peygamberlerle ve olaylarla karşılaşılır.

İkinci kat göğe çıktıklarında Yahyâ ve Îsâ peygamberlerle karşılaşır ve onlarla selamlaşır. Sonra üçüncü kat göğe çıkarlar, orada da Yûsuf peygamber bulunmaktadır.

Dördüncü kata çıtıklarında İdrîs peygamberle tanışırlar. Arkasından beşinci kat göğe çıkarlar. Bu katta da yine bir peygamber olan Hârûn ile görüşürler. Altıncı kata geldiklerinde Mûsâ peygamberle tanıştırılır. Daha sonra birkaç kez daha Hz. Mûsâ'nın yanına inip çıkacaktır. Ve son kat olan yedinci kata varırlar. Yine aynı soru cevap olayından sonra orada da Hz. İbrâhîm ile karşılaşıp selamlaşırlar.

"Bütün bu menâzil ve menâzırdan sonra karşıma Sidre-i Müntehâ sahası açıldı." (Akar, 1980: 23) Sidre-i Müntehâ kökleri dört nehir tarafından sulanan muazzam büyüklükte bir ağaçtır. Bu nehirlerden ikisi batînidir ve cennetde bulunmaktadırlar. İkisi de dünyâda bulunan Nil ve Frrat nehirleridir. Bu katta Beytü'l- Ma'mûr'un kendisine gösterildiğinden bahseden $\mathrm{Hz}$. Muhammed burada ümmeti için kendisine elli vakit namaz farz kılındığından bahseder. Geriye döner ve Mûsâ'nın yanına gelir elli vakit namazı duyan Mûsâ, ümmetinin o kadar namazı

3 Bu hadisler için bkz. Müslim, İman, 259; Buhârî, Bedü'l-Halk, 6; İbni Hanbel, Müsned, c.5, 143. 
kılamayacağını söyler ve geri gönderip Allah'tan vakitlerin sayısını azaltmasını istemesini söyler, bu olay da birkaç kez tekrarlanır. En nihayet beş vakit namaza indirilince artık Hz. Muhammed Allah'ın huzuruna geri dönmez ve bundan sonra geriye döner.

Hadislerden anlaşıldığı üzere Hz. Muhammed Arş-1 âlâ olarak adlandırılan dokuzuncu kata kadar çıkmıştır. Mi'râc hadisesini anlatan ilk dönem eserlerde de genel olarak bu hadislerin etkisi görülmektedir ve mi'râciyeler oldukça sade bir dille anlatılmıştır. Ancak X. yüzyıldan sonra yazılan mi'râciyelerde olaylar daha süslü bir dille hikâyeleştirilmiş ve gök katları artık birinci, ikinci, üçüncü diye adlandırılmak yerine gezegenlerin isimleriyle anılmaya başlanmıştır. Bunun sebebi ise Fergânî'nin Batlamyus'un önemli eseri Almagest'in çevirisini yaparak önce İslâm dünyasına sonra da Batı dünyasına kazandırmış olmasıdır. Bilhassa Klasik Türk Edebiyatı́nın Anadolu sahasında yazılmış olan mi'râciyelerde artık Hz. Muhammed, Kudüs'ten sonraki yolculuğunda önce Ay'a (Mâh), sonra Merkür'e (Utârid) arkasından Venüs'e (Zühre), Güneş'e (Mihr), Mars'a (Merih), Jüpiter'e (Müşteri) ve nihayet Satürn'e (Zühâl) çıkar. Sidretü'l-Münteha'da sekizinci kat burçlar gezegeni vardır. Ve hepsinin üzerinde Arş-1 âlâ veya Atlas-1 Gerdûn denilen bütün gök katmanlarını içine alan en son gök katı bulunmaktadır.

Bu çalışmada farklı mi'raciye örnekleri incelenmiş olup Şeyh Galib'in ölümsüz eseri Hüsn ü Aşk'ın içerisinde bulunan 94 beyitlik mi' râciye bölümü ve İsmail Hakkı Bursevî̀nin Mi'râciye adlı eserleri karşılaştırmaya esas alınmıştır. Bu eserler, hem klasik Türk Edebiyatında yazılmış mi'raciyelerin bütün özelliklerini içine alması hem de İlahî Komedya ile karşılaştırılabileceğimiz ortak motiflerin fazla olması nedeniyle seçilmiştir. Eserlerde, önce bu yolculuklar genel kavramlar çerçevesinde karşılaştırılarak neden, zaman ve mekân gibi çerçeve bilgiler verilmiş; daha sonra da ortak motifler ve farklılıkları gösterilmeye çalışılmıştır.

\section{Yolculuğun Nedenleri:}

Hadis kitaplarından ve konu ile ilgili ayetlerden anlaşıldığı üzere, Hz. Muhammed'in mi'râcının tek bir sebebi bulunmamaktadır. Öncelikle mi'râcın olduğu döneme bakmak gerekir, hicretten yaklaşık bir yıl önce olduğu tahmin edilmektedir. Hz. Muhammed ve ona inanan Müslümanlar Mekke'de oldukça sıkıntılı bir dönemden geçmektedirler. Müşrikler tarafından hem maddi hem de manevî anlamda tecrit edilmişlerdir. Hz. Muhammed kısa bir süre sonra önce koruyucusu olan amcası Ebu Tâlib'i sonra da eşi Hz. Hatice'yi kaybeder. Bir çıkış yolu arayan Hz. Muhammed Taif'e giderek orada inancını yaymak ister ancak orada da durum Mekke'dekinden farklı olmaz hatta biraz daha ileri giderek taşlarla saldırırlar. Bütün bunların yanında Ebu Süfyân'ın Peygamber'i fakirliğinden dolayı aşağılaması gibi olumsuz etkilerin temelinde Allah'ın O'nun metânetini artırmak ve ilerde sahip olacağı nimetleri göstermek olmalıdır (Akar, 1980: 243). Bütün bu 
sıkıntılara, sabır ve metanetle ve Allah'a duyduğu aşk ile katlanan Hz. Muhammed, bu daveti almayı hak etmişti. Bu konu Mi'râciye' de şöyle anlatmıştır (Bursevî, 2007):

Cân kim hem-râh-ı ışk-ı yâr ola

Âkıbet ser-menzile seyyâr ola

Bu sebepdendür ki Hallâk-ı cihân

Çün nazar kıldı kulûba der-nihân

Gördi kalb-i Ahmed'i a'şak idi

Hançer-i ışk ile san münşakk idi

...

Işk-ı âşı ç̧ün bula dilde kemâl

Eyleye ma'şûk ana arz-ı cemâl

$\ldots$

Tâ göre 'âyât-ı kübrâ'yı kamu

Tâ bile esrâr-ı Hakk'ı mûu-be-mî

Tâ ire nûr-ı cemâlinden eser

Ola ru'yetle münevver çeşm-i ser

(Bursevî, 2007: 44-45)

Ülkesindeki siyasi karışıklığın ortasında doğan Dante, gençlik yıllarında kendisi de politikaya atılmış, ancak daha sonra iktidarla arası açılınca yargılanmış ve para cezası almıştır. Parayı ödemeyen Dante daha sonra ölüm cezasına çarptırılmıştır. Floransa' da bu cezayı aldığında kendisi Roma'da sürgündedir. Papa'nın değişmesi ve Henri VII'nin kral olması onu ümitlendirir. Artık istedikleri olacak, din ve devlet işleri birbirinden ayrılacaktır. Açıkça Henri VII'yi destekleyen Dante, Floransalı sürgünlere 1311 yılında tanınan geriye dönüş listelerinde yer almaz. 1315 yılında Dante için de af çıkar ancak bu sefer de o geriye dönmez. Ömrünün son altı yılını Verona ile Ravenna arasında geçiren şair 1321 yılında sürgündeyken sıtmadan ölür (Dante, 2001).

Memleket hasretinin yanı sıra çocuklarından ve eşinden de ayrı düşmüştür. Çocukluk aşkı Beatrice başkasıyla evliyken genç yaşta ölmüştür. Dante, bu kadar düzensizlik içerisinde ülkesi ve inancı için kaygı duymakta olduğu bir dönemde İlahî Komedya'yı yazmaya başlar. Nitekim Teksoy, Dante'nin İlahi Komedya'yı kaleme alma sebeplerini şöyle ifade etmektedir: "Dante, iç dünyasındaki kargaşanın çözümünü Tanrı'ya sı̆̆ınmada bulur. Yeniden şiire ve idealleştirdiği Beatrice sevgisine döner. Insanlara bu arada kendine doğru yolu göstermek amacıyla İlahi Komedya'yı yazar. Tanrı'nın insanlar için öngördü̈̆̈̈ iki amaç vardır. Bunlardan ilki yeryüzü mutluluğudur. Insan ahlak kurallarnna uyarak, düşünsel yeteneklerini geliştirerek bu amaca ulaşabilir. İkinci amaç ölümden sonraki sonsuz yaşamdır. İnsanın bu amaca ulaşması için de Tanr'ya inanması, onun koyduğu kurallara uyması gerekir. Bu amaçların gerçekleşmesinde 
imparator ile papa insanlara yol gösterir. Ne var ki, insan kendi kendine de yeryüzündeki davranışların düzenleyebilir, Tanr'nın varlı̆̆ının bilincine vararak, ruhunun ölümsüzlüğ̈̈nü sağlayacak bir yaşam sürebilir. İşte iç dünyasının sesini dile getiren Dante, İlahi Komedya'da şiir aracılığıyla insanlara bu yolları gösterir." (Dante, 2001: 17)

Dahası İlahi Komedya'nın ilk dizeleri de bu ruhsal durumun ipuçlarını bize vermektedir:

Yaşam yolumuzun ortasında

Karanlik bir ormanda buldum kendimi,

Çünkü doğru yol yitmişti.

Cehennem, I/1 s.33.

Sürgünlüğün ne kadar acı olduğunu şu dizelerde anlatmaktadır:

En sevdiğin ne varsa hepsini bırakacaksin;

Bunun, gurbet yayının attı̆̆

Illk ok olduğunu anlayacaksin

Başkasının ekmeğinin ne denli tuzlu

Başkasının merdiveninden çıkmanın

Ne denli zor olduğunu göreceksin

Omuzlarma en büyük yükü de,

Bu vadiye düşerken sana eşlik edecek

Budala sürüsü bindirecek;

Cennet, XVII/55-63, s.675.

\section{Zaman}

Mi'râcın zamanı kesin değildir. Bu konudaki rivayetlere göre mi'râc hicretten bir yıl veya iki yıl önce gerçekleşmiştir. Türklerde, anma tarihi olarak recep ayının 27'si kabul edilmiştir. Gün ve yılda ittifak olunmasa da bilinen şey bu davetin ve mi'râcın gece olmasıdır. Konu ile ilgili ayetlerin olduğu sûrenin adı da İsrâ, gece yürüyüşü anlamındadır. Gece sevgililerin gözlerden uzak buluşma anıdır. Bu durum Şeyh Galip'in eserinde, (Doğan, 2002) ve Bursevî́nin Mi'râciye'sinde şöyle şiire dökülmüştür:

Bir şeb ki sarây-ı Ümmühânर̂

Olmuşdı o mâhın âsmânı

Yüz sürmege geldi hâk-i pâya

Da'vetli bulundılar alâya

Ol leyle için sipihr-i gerdân

Etdi niçe bin sabâhı kurbân

Çün âb-ı hayât o şâm-ı enver

Rengi siyeh idi mevci ahdar

(Doğan, 2002: 4-5) 
İrdi müjde bir gice nâgâhdan

Geldi Cibrîl-i emîn dergâhdan

...

Gicede da'vetde hikmet bu idi

Kim meşâm-ı halka şeb bî-bû idi

$\cdots$

Bir de budur şebde var strr-ı fenâ

Eyledi ana anın'çün i'tinâ

Kıldı da'vet şeb içinde Hazreti

Tâ fenâda göre hasret hasreti

(Bursevî, 2007: 46))

Dante'nin yolculuğu da 1300 senesinin Paskalya öncesi Cuma akşamında başlar.

Bu Hristiyan dünyası için önemli bir tarihtir; Hz. İsâ 34 yılında Paskalya' dan önceki Cuma günü öğle vakti ölmüştü (Leonhard, 2012).

Gün bitiyordu, kararan hava

Yeryüzündeki canliların yorgunluklarnı

alıyordu; ben de tek başıma,

belleğimin yanilmadan aktaracağ

yolculuğu, tanık olacağım acıları

karşılamaya hazırlanıyordum.

Cehennem, II/1-6

O zaman biraz dindi

O sikıntilı gecede

Yüreğimin gölüne çöken korku.

Cehennem, I/19

\section{Mekân}

Hz. Muhammed mi'râc davetini aldığında amcasının kızı Ümmü Hânî́nın evindedir. Burası başlangıç noktasıdır. Sonrasında önce Mescid-i Aksa'ya yani Kudüs'e götürülmüş oradan da gökyüzüne urucu başlamıştır. Gök katlarıyla ilgili daha detaylı bilgi verilecektir.

Dante'nin yolculuğa başlamadan önce mevki olarak tam olarak nerede olduğunu bilmiyoruz ancak şiirlerinden edindiğimiz bilgilerle bir yön çizmemiz mümkün. Öncelikle karanlık bir ormanda kaybolduğundan bahseder bu yolculuğun başladığı noktadır, hem gerçek anlamda hem de mecazî anlamda. Çünkü eserin yazıldığı çağlarda İtalya' da vahşi hayvan ve hayaletler, iyiler ve kötülerin bulunduğu balta girmemiş ormanlar hâlâ vardır. (Leonhard, s. 12). Bir başka ortak nokta ise Dante, Cehennem'in Kudüs'ün altında olduğunu yazar, hatta Cennet de yine gökyüzünde Kudüs'ün hizasında bulunmaktadır. 


\section{Arınma}

Her iki eser incelendiğinde, karşımıza bir arınma süreci çıktığını görüyoruz, Hz. Muhammed'in kalbinin zemzem ile yıkanması, kalplerde yaratılıştan var olduğu söylenen sevde adlı kara noktanın tamamen temizlendiği anlatılır. Aslında arınma eylemi bize cennete ancak günahlarından tamamen kurtulmuş kişilerin gideceğini gösteren semboldür. "Ben Mekke'de iken evimin sakfı (ansızın) yarıldı. Cibrâ̂l (a.s.) indi. Göğsümü yardıktan sonra (içini) zemzem suyu ile yıkadı. Sonra hikmet ve îmân ile (lebaleb) dolu altın bir leğen getirip içindekini göğsümün içine boşalttı ve göğsümü kapa (yıp üzerini mühürle)di. (Akar, 1980: 16).

Yine Dante de bir çeşit ruhsal arınmadan geçtiğini anlatır. Ona göre yolunu şaşırmış olan ruhu günaha batmış, Tanrı'nın yolundan uzaklaşmıştır. Arınmasının ilk aşaması Cehenneme girmesi ve orada günahkârları ve çektikleri azapları görmesidir. Bu olaylara şahitlik etmesi bile onun günahlarından af dilemesi için yeterlidir, daha sonra Araf'a çıkar ve burada daha kapsamlı bir arınma yaşar; Dante'nin yolculuğu önce yer altında olduğuna inanılan cehenneme doğru başlamıştır. Cehennemde günahkâr kullar ve onların çektikleri azapları gören Dante -ki kendisinin de bir günahkâr olduğunu ve yolunu kaybetmiş bir şekilde bir arayış içinde olduğunu söyler- uhrevi âlemin ikinci menzili olarak gördüğü Araf'a gelir. Araf cehennemde günahlarının bedelini ödeyen kulların cennete çıkmadan önce yedi ölümcül günahtan arındıkları yedi kattan ibaret olan ve yukarıya doğru basamaklarla çıkılan bir mekândır. Dante de bu bölgelerin tamamını tek tek çıkarak her bir katta bir günahından arınıp cennete varmaya hazır olur. Rekin Teksoy bu hususu şöyle değerlendirir: "Âraf'taki cezanın amacı, ruhun eğitilmesi, işlediği günahlardan pişman olmasının sağlanmasıdır. İyilik-kötülük karşıtlığının sonucu Cennet-Cehennem ikilisine eklenen Âraf, bir değişim merkezidir. Cehennem'in yıldızsız göğünden, sonsuz karanlığından gün ışı̆̆ına, gece gündüz düzenine kavuşan ruhlar burada içsel bir değişim geçirir."(Dante, 2001: 22)

Insan ruhunun armop da

Cennet'e çıkmayı hak ettiğ $i$

Ikinci beldeyi anlatacă̆ım şimdi.

Araf, I/4

Bak şurada Euone akmakta:

Oraya götür onu ve bildiğin gibi

Güçlendir, yarı ölü belleğini.

Bu kutsal mi kutsal sudan, yeni yapraklara

Bürünmüş taze bir fidan gibi canlanıp da,

Arınmış olarak eski yerime vardığımda,

Çıkmaya hazırdım artık yıldızlara.

Araf, XXXIII/127-129, 142-145 


\section{Binitler}

Her iki yolculukta da gökyüzüne yükselirken bazı araçlar mevcuttur. Bunlar mi'râcîyelerde açıkça bahsedilmektedir. Dante bu konuda bilinmezlik içindedir.

"Daha sonra katırdan küçük ve merkepten büyük beyaz bir binit getirdi. Bunun adı Burak'tır ki o, adımını gözünün erişebildiği yerin müntehasına atardı." "Sonra âlî makamlara çıkacak bir Mi'râc, bir merdiven kuruldu. Buna Cibrîl ile bindirildim ve onunla berâber yükseldim." (Akar, 1980: 16), bazı hadis kitaplarında Hz. Muhammed'in sekizinci kat göğe kadar Burak ile çıtığından bahseder. Sekizinci kattan sonra Cebrail'in çıkmasının yasak olduğu Arş-1 âlâ'ya Hz. Muhammed efsanevi bir kuş olan Refref ile çıkmıştır (Uludağ, 2002).

Adın kodılar Burâk-ı yektâ

Geldi ayağına arş-ı a'lâ

(Doğan, 2002: 4)

Vâr idi yaninca Cennetden Burâk

Kim basardı ayă̆ın gayet ırâk

...

Çün süvâr oldı Burâk'a Mustafâ

Mescid-i Aksấ'ya geldi bâ-safâ

(Bursevî, 2007:46-47)

Dante'nin yolculuğu önce Cehenneme doğru Kharon'un kayığı ile başlamıştır, daha sonra Araf'a tırmanarak çıkarlar, Araf'ta da durum değişmez ve yedi katı da tırmanarak, yürüyerek aşarlar. Dante'de Araf'ın son katında Beatrice, Grifon'un ${ }^{4}$ çektiği zafer arabası ile Âraf'a gelir ve Dante'ye kendisini takip etmesini söyler. Ancak Dante, yukarıya doğru çıktıkça şaşırır, çünkü beden olarak mı yoksa ruhu ile mi çıktığını anlayamaz.

Yedinci kattan itibaren yukarılara doğru yükselen merdiven vardır. Cennet'in birinci katına araç ile çıkarlar ancak sonrasında kademe kedeme kendisini bir sonraki gezende bulan Dante buralara nasıl çıktığını anlatmaz, aslında kendisi de bilmemektedir.

Dedim ki: "Şaşkınlıktan kurtulup rahatladım;

Ama şimdi de bu hafif nesnelerin arasindan

Nasıl yükseldiğime ermiyor aklım."

Cennet, I/97

Bir merdiven gördüm, güneş ışı̆̆ı vurmuştu

Altın renginin üstüne,

Gözümün erişemediği yüksekliğe çıkıyordu.

Basamaklardan aşağıya doğru

4 "Griffon" veya "Griffin", genellikle aslan vücutlu, kartal kanatlı ve kafalı mitolojik yaratıktır. Farklı betimlemelerinde hayvanın 4 ayağı da aslan ayağı, yalnız arka ayakları aslan ayağı veya tüm ayakları kartal ayağı olabilir. 
Binlerce ışık iniyordu,

Gökteki ışıkların tümü sanki ondan ışıyordu.

Cennet, XXI/28-29

\section{Aşama Aşama Menziller}

Mi'racdaki menziller hadis kitaplarında birinci kat, ikinci kat, üçüncü kat gibi sadece sayılarla anlatılmaktadır. Ancak X. Yüzyıldan sonra yazılan mi'râciyelerde yavaş yavaş felekler göğü olarak anılmaya ve her katta da bir felekten bahsedilmeye başlanmıştır. Dante ise Cennet'e çıkmaya başladığ1 andan itibaren çıktığı her katta bulunan gezegeni mitolojik özelliklerine gönderme yaparak anlatır.

Öncelikle İslâmî kaynaklarda bilhassa sahih hadis kitaplarında bahsedilenin dışına çıkmamaya çalışan şairler bilimsel olarak da hangi katta hangi feleğin olduğunu bilmiyorlardı. İspanyol akademisyen Palacios bu konudaki yargısını yazarken aslında biraz haksızlık yapmıştır; "İki anlatıda da, gökbilimdeki gökyüzü katmanları kadar safha vardır. Bu katmanların isimleri ve sayıları konusundaki farklılıklar, eserini bu bilgisiz Müslüman hayalcilerden beş yüz y1l sonra yayınlamış olan kültürlü bir şairin üstün bilimsel bilgisinden başka bir şeye işaret etmez." (Palacios, 2015: 34,). Palacios, bu tezine dayanak olarak sadece İbn-i Arabî’yi kaynak olarak gösterir ve Dante'nin Ârabî’nin astronomi bilgilerini alıp kitabında kullandığını iddia eder. İbn Ârabî de bu bilgilerin kendisine ilham yolu ile verildiğini söylemektedir. Palacios, bu konuda yazdığı bahse konu olan eserinde milliyetçi bir üslup kullanmış ve nerdeyse İbn Arabî’nin isminin geçtiği her yerde "Mursiyeli Arabî" diyerek onun Endülüslü olmasına vurgu yapmıştır. Oysa feleklerin bu şekilde sıralanışı ve gezegenlerin adlandırılmasını bilimsel olarak kitabında ilk kez kullanan İskenderiyeli bilim adamı Batlamyus'tur. II. yüzyılda yaşadığı bilinen Batlamyus'un meşhur eseri Almagest, IX. yüzyılda Özbekistan, Fergâna'lı Türk bilim adamı Ebu el-Abbas Ahmed bin Muhammed bin Kesir elFergani tarafından sadeleştirilerek özet olarak Arapçaya çevrilmiştir. Bu eser daha sonra Latince' ye çevrilmiştir. Dante' nin bilgisinin kaynağı da Fergani'nin eserinden ve Batlamyus teorisinden başkası değildir. ${ }^{5}$ Asin Palacios'un bu tezi İtalya' da hâlâ tartışılmaktadır. ${ }^{6}$

\footnotetext{
5 Batlamyus Teorisi: Klaudyos Ptolemaios, İskenderiyeli Yunan matematikçi, coğrafyacı ve astronom. Yaklaşık olarak 85 ve 165 yılları arasında yaşadığı kabul edilir. Geç İskenderiye Dönemi'nde yaşamış ünlü bilim adamlarındandır. Almagest adlı eseri ile bilim dünyasına önemli katkılar sağlamıştır. Dünyayı merkez alarak gezegenlerin sıralamasını ve hesaplamalarını yapmıştır. Teoriye göre dünyanın etrafında hareketli yedi adet gezegen bulunmaktadır bunların en yakından en uzağa göre sıralanışı şu şekildedir: Ay, Merkür, Venüs, Güneş, Mars, Jüpiter, Satürn. Bu yedi gezegenin ardından burçlar gezegeni olarak da adlandırılan göğün sekizinci katı gelmektedir, eflak-ı sabite de denilen takımyıldızlar bu katta bulunmaktadır. Bunların sıralaması ise şu şekildedir: Koç, Boğa, İkizler, Yengeç, Aslan, Başak, Terazi, Akrep, Yay, Oğlak, Kova ve Balık. Bunların hepsinin üzerinde ise Arş-1 Âla denilen dokuzuncu kat gök bulunmaktadır. (El-Fergânî, (2012), Astronominin Özeti ve Göğün Hareketlerinin Esasları, Çev. Yavuz Unat, T.C. Kültür ve Turizm Bakanlığı, Ankara.)

${ }^{6}$ Arap kültürünün taşra lirik şiiri ve Dante ' nin İlahi Komedya eseri üzerindeki yansımaları. "Said'in deyimiyle Asín Palacios saf akademik bir araştırmacı olmaktan ziyade planlı bir şekilde estetik olarak süsleyip, programlı bir biçimde itibar sahibi olması sağlanmış ve yüksek
} 
Varılan menziller anlatılırken Klasik Türk Edebiyatı şairleri feleklerin Türk mitologyasındaki özelliklerine göndermeler yaparak mi'râc olayına edebî söz ustalığı katarken Dante'de bilhassa Yunan mitolojisinden istifade etmiştir. Aralarındaki en önemli fark ise İslâm inancında gökyüzü dokuz kat olarak tasvir edilirken Hristiyan dünyasında on kat olduğu ve Tanrı'nın onuncu katta bulunduğuna inanılmaktadır. Çünkü Hristiyanlar için on mükemmel sayıdır.

Çün bastı sipihr-i evvele pâ

Oldı iki pâre bedr-i ra'nâ

Tâ halka ıyân ola mücerred

Kim devr-i kamer mi devr-i Ahmed

(Doğan, 2002: 37)

Hz. Muhammed'in ayı ikiye bölmesi mucizesine gönderme yapmaktadır. Yine aşağıda bulunan beyitlerde yedi feleğin hem sırasıyla kaçıncı katta olduğu hem de adları verilmiş ve ayırt edici özelliklerinden bahsedilmiştir:

Azmeyledi vahy-i vârid üzre

Vardı felek-i Utârid üzre

Çün geldi o şâir-i felek-câh

$\mathrm{Ol}$ şâhdan oldı ma'zeret-hâh

Afveyledi nâme-i siyâhın

Hassân'e bağış̧ladı günâhın

Meb'ûsina rehber oldı bâis

Açıldı der-i sipihr-i sâlis

Zehrâsin edip şefí Zühre

Aforndan o şâhın aldı behre

Çârüm felegi kılınca seyrân

Fahr etdi dü bâre çâr erkân

mertebelere yerleştirilmiş bir entelektüeldir. Militan bir vatanperverdir. Bir makalesinde Faslıların niçin Franco ile yan yana cumhuriyetçilere sosyalistlere ve komünistlere karşı mücadele ettiklerini açıklarken Arap Endülüs birlikteliğinden gelen ortak kültür ve ortak maneviyat ve Hristiyan ve Müslümanların En büyük ortak düşmanına (komünizm) atıfta bulunmaktadır." Stefano Rapisardo'nun yaptığı açıklamalar ve konu hakkındaki düşüncelerini özetleyecek olursak Palacios, açıkça İspanyol Arapçıllı̆ı yapmaktadır ve ileri sürdüğü fikirler büyük oranda ideolojiktir. (Rapisardo, Stefano, La Escatologia musulmana di Asin palacios nella cultura italiana contemporanea. Una ricezione ideologica? 15-16 Nisan 2005, Udine Universitesi, çev. Kerim Yılmaz, 2017.) 
Feyz aldı mülâhdan Mesîhâ

Tekrârdan oldı sanki ihyâ

Berk urdı o şeb-çerâ̆̆ $ı$ câvid

Şermiyle zemîne girdi hurşîd

Çün târem-i hâmis oldı menzil

Mirrîh'e erişdi hadşe-i dil

Kan ă̆layıp etdi özre âheng

Dâmân-ı sipihri kıldı gül-reng

Afoetdi o şâh-ı âsmân-rahş

Azrâil'e kıldı cürmini bahş

Çün şeş cihet oldı kâm-hâhı

Çarh-ı şeşüme erişdi râhı

Tâ ede o şâh-ı heft-iklîm

Kâdî-i sipihre şer'i ta'lîm

Teblî̆g kılıp Cenâb-ı Hak'dan

Nehy eyledi hükm-i mâ-sebakdan

Men' oldı kehânet ile tencim

Zâhirle müzâhir oldı tanzim

Çün erdi sipihr-i heftümîne

Bahş etdi saâdet âlemine

Keyvân şefî́ edip Bilâl'i

Böyle deyip etdi rûy-mâlî

Besdir bana bu şeb özr-hâhî

Bâlâ-ter-i reng kıl siyâhı

(Doğan, 2002: 38-42)

Dante de Cennet'in II. Kantosundan itibaren gezegenleri sırasıyla çıkmıştır. Dante bu şekilde çıktığı her katı kendi özel sembolleriyle anlatır; meselâ üçüncü göğe çıkışında bahsettiği Kıbrıslı kız Venüs'ten başkası değildir. Diğer katlarda da 
gezegenlerin isimlerini açıkça vermek yerine özelliklerine göndermeler yaparak anlatır:

Birinci katta gezenlerden Ay vardır, ikinci krallık diye bahsedilen Merkür ve üçüncü ilmekteki Kıbrıslı Kız ise Venüstür.

Düşüncelerimi okuyan kadın ve

"Tanrı'yı düşün, dua et" dedi,

"gökteki ilk yıldıza ulaştırdı bizi"

Cennet, II/28-30

Ve daha kirişin titreşimi

Bitmeden hedefi vuran bir ok gibi,

İkinci krallığa koştuk biz de.

Cennet, V/91-93

Eskiden dünyada yanlı̧̧ bir inanç vardı.

Üçüncü ilmekte dönen Kıbrısh

Kızın, çılgın sevda ışınları yaydığı sanılırdı;

Cennet, VIII/1-3

Yeri ve göğü ışığı ile aydınlatan dördüncü kattaki hayat kaynağı tabii ki güneşten başkası değildir. Yine rengine gönderme yapılarak bahsedilen beşinci gezegen ise Kızıl Gezegen adıyla tanınan Mars'tır.

Dünyaya göklerin damgasinı vuran,

Işığı ile zamanı ölçmemizi să̆layan

Doğanın en büyük görevlisi,

Yukardda belirtilen noktaya erişmişti,

Her gün biraz daha erken doğduğu

Sarmallarda yol aliyordu;

Cennet, X/29-33

Her zamankinden daha kırmızı görünen

Yıldızın alev alev gülümsemesinden,

Yükselmiş olduğumu anlamıştım.

Cennet, XIV/85-87

Bu yıldızlı ışılar da, Mars'ın derinliklerinde

Bir çemberin kesişen iki çapı örneği

Kutsal işareti çiziyorlardr.

Cennet, XIV/100-102

Beni içine alan ılımlı altıncı yıldızın

Solgunluğu da öyle göründü

Gözlerime, ben o yana dönünce

...

Sonra beşinci sözcüğün M harfinde

Straya girdiler, öyle ki o noktada

Altın süslemeli gümüşe dönüştü Jüpiter. 
Cennet, XVIII/ 67-69/94-965

Yedinci göğe yükseldik şimdi,

Alev alev Aslan'ın göğsünün dibinden

$O$ da ışııların gönderiyor yeryüzüne

Cennet, XXI/13-15

Dante, sonraki katlarda da aynı taktiği uygulamıştır, ancak dokuzuncu kata kadar çıktıktan sonra onuncu katı tasvir etmiş ama oraya gitmemiş, tanrının ışığını uzaktan seyretmekle yetinmiştir. Onuncu kat farklı bir yapıya sahiptir, basamaklarla içine inilen büyük, beyaz bir gül şeklinde anlatılmıştır ve her basamakta da bir aziz veya peygamber, peygamber eşleri ve tabii ki Beatrice vardır.

\section{Karşılaşılan kişiler}

Mi'râcın her aşamasında Hz. Muhammed öncelikle peygamberlerle karşılaşır ve onlarla tanıştırılır, selamlaşır. Meleklerle karşılaşır, kişi olarak anne ve babasını görür ancak onlar cehennemdedir.7 (Akar, 1980: 118) Hz. Muhammed önce Cebrail ile karşılaşır ki bu da hem Allah'ın davetini getirmesi hem de bütün yolculuk boyunca kendisine eşlik ettiği için planlı bir karşılaşmadır. Gökyüzünde ise her felekte bir veya birkaç peygamberle karşılaşır, bunlar sırasıyla şunlardır:

Birinci kat gökte Ay feleği vardır ve burada Hz. Âdem bulunmaktadır. İlk insan ve ilk peygamber, bütün insanların atası olarak bu felekte oturmuş sağına bakıp gülümsemekte soluna bakıp ağlamaktadır. Nedenini merak eden Hz. Muhammed'e açılama olarak sağ tarafta soyundan gelip cennete giden insanların, sol tarafta ise cehennemde azap gören evlatlarını gördügünden bahsedilir. Bu nedenle birinci kat Ay feleği bir tür berzah katı olarak değerlendirilmektedir: "Kapı açılınca semâ-i dünyanın üstüne çıktık. Bir de göreyim ki bir kimse oturmuş, sağ tarafinda bir takım karaltılar, sol tarafinda da diğger karaltılar var. (o kimse) să̆ tarafina baktığında gülüyor, sol tarafina baktığında ă̆lıyor. (O zât): 'Hoş geldin, safâ geldin sâlih oğlum.' Dedi. Cibril'e: 'bu kim?' diye sordum. "Âdem (s.a.s.)'dir. Sağında, solunda olan bu karaltılar da evlâdının rûhlarıdır. Sağında olanları ehl-i Cennet, sol tarafinda olan karaltılar da ehl-i Nâr'dır. Sağına bakınca güler, sol tarafina bakınca ağlar.' Dedi." (Akar, 1980: s.16)

İkinci kat gökte Yahyâ ve Îsâ peygamberlerle karşılaşırlar, üçüncü katta Yûsuf peygamberle, dördüncü katta İdrîs peygamber ile beşinci semâda Hârun peygamber, altıncı kat semâda Mûsâ peygamber ile tanıştırılır. Yedinci kata geldiklerinde babası İbrâhîm peygamber ile tanışıp selamlaşır. Bu karşılaşmalar

${ }^{7}$ Hakim Süleyman Ata'nın XII. yüzyılda yazmış olduğu Mi' râcîye' den alıntı yapılmıştır: “Hz. Peygamber Cehennem'i seyrederken anne ve babasını görür. Onlar kendisinden rahmet ve şefâat dilerler. Hz. Peygamber üzülür. Tanrı' dan "bir gönüle iki dost asla sığmaz, ya anneni ve babanı ya da ümmetini seç." diye nida gelir. Hz. Peygamber ümmetini tercih eder:

Resûl aydı ay Rahmân ata anam iki cân

Ümmetlerim min elvân kabul kılgıl didi-ya

Atadın hem kiçer men anadın hem kiçer men

Ümmetlerim tiler men 'afiv kılgil didi-ya 
hadis kitaplarında bu şekilde verilmiştir. Hadislerden alınan bu bilgiler mi'râciyelerde de hemen hemen aynı sıra ile verilmiştir.

Kıldı çün çarh-ı nühustîn harîm

Oldı ceddi Âdem'e zayf-ı kerîm

...

Rûh idi Âdem tahayyüzden beri

Ders-i tecrîd idi dâim ezberi

...

Biri budur berzahîdur ol semâ

Nûr u nâra müstevâdur dâimâ

Anun'çün nesline idüp nigâh

Gâh gülerdi Âdem vü ağlardı gâh

40, 42,46,49 (Bursevî, 2007: 52-53)

Oldı câyı âsumân-ı heftümîn

Sâbitü'l-bünyândur anda hemîn

...

Gördi hem ol halkı Hallâk'a delil

Kim oturmış anda İbrâhim Halîl

79, 85(Bursevî, 2007:66)

Dante' nin astral yolculuğunda da daha önceki bölümlerde olduğu gibi gerçek hayatta tanıdığı, hakkında bilgi sahibi olduğu veya kutsal kitaplarda ismi geçen melekler, azizler, keşişler, rahibeler ve mukaddes kişiler karşısına çıkar. Özellikle de Arş-1 âlâya çıkarken merdivenin basamaklarında gördüğü kadın karakterler Dante' nin bu konudaki hassasiyetine de 1şık tutacak bir öneme haizdir.

Öncelikle Âraf'ın yedinci katından itibaren onu karşılayan ve cennette ona rehberlik eden Beatrice, Meryem, Rachel, Havva, Maria Magdelana, Lucia, Meryem'in annesi Anna, Sarah, Rebecca, Judith, Ruth. Bu isimlerden de anlaşılacağı gibi Hz. İsâ ve onun geçmişinde yer alan annesi, ninesi büyük annesi gibi ailenin kadınları ve diğer peygamberlerin eşleri Havva ile birlikte Cennet'in sekizinci katındadırlar. Yine bu katta Hz. İsâ'dan önce gelmiş bazı peygamberler ve Cebrail de dâhil büyük melekler bulunmaktadır. Erkeklerin içinde bazı havariler ve azîzlerin bulunması da Dante'nin inancı hakkında bize yeterince bilgi vermektedir. Tanrı'nın ışı̆̆ının görüldüğü dokuzuncu kata Aziz Bernard'ın rehberliğinde çıkar. [Fransa' da Claivaux manastırının baş keşişi ermiş Bernard (1090-1153)]

Kendi ailesinden de büyük dedesinin dedesi Cacciaguida ile karşılaşır ve onunla hem ülkesinin tarihini hem de kendi soyu hakkında konuşur.

\section{Ağaçlar:}

Hem mi'râciyelerde hem de Dante'de olağanüstü büyüklükte bir ağaçtan bahsedilir. Mi'râcda bahsedilen ağaç sidretü'l-münteha diye adlandırılır. "Bütün bu menâzil ve menâzırdan sonra karşıma Sidre-i Müntehâ sahası açıldı." Çeşitli hadis 
rivayetlerinde yapraklarının yıkanmada kullanılması sebebiyle sidr, ayrıca âyetteki konumu itibariyle sidretü'l-müntehâ yer alır.

$\mathrm{Bu}$ açılamaların ortak noktası sidretü'l-müntehânın bir sınırı ifade etmesidir. Burası, Mi'rac gecesi Hz. Peygamber'in mazhariyeti dişında büyük meleklerin ve peygamberlerin ötesine geçemediği, yaratılmışların ilminin ulaşabileceği son nokta olarak kabul edilir. Yaygın kanaate göre Hz. Peygamber Mi'rac gecesi Cebrâil ile sidretü'l-müntehâya kadar gitmiş ve Cebrâil'in daha ileriye gitmesine izin verilmediği için kābe kavseyne olan yolculuğuna refrefle devam etmiştir. Bu sebeple sidretü'l-müntehâ Cebrâil'in makamı sayılmıştır. Ayrıca bunun illiyyîn olduğu yolunda görüşler vardır.

Ol seyrde mâverâ göründi

Tâ Sidre-i müntehâ göründi

Açıldı der-i harîm-i vuslat

Kurbet girü kaldı geldi vahdet

Cibrîl'de acz olup hüveydâ

Elfâzı bırakdı anda ma'nâ

(Doğan, 2002: 46)

Çünki old Sidre'nün seyri tamam

Eyledi Kürsî'ye andan ihtimâm

Kaldı anda Cebrâil ile Burâk

Kim zarûrî idi ol demde firâk

...

Geldi Refref düşdi pây-ı hazrete

San mülâkî oldı hasret hasrete

(Bursevî, 2007:79-80)

Dante'de ağaç motifi Âraf'ın son katında karşımıza çıkar. Burada Beatrice'nin araba ile Cennetten inerek Griffin'i bağladığı yaprakları ve çiçekleri olmayan devasa bir ağaçtan bahseden Dante, yanına yaklaştığında ağacın daha çok büyüdüğünü ve dallarının yeşerip çiçeklendiğine şahit olur. Tekvin 2:6 ayette geçen iyiliği ve kötülüğü bilme ağacıdır. Bu ağaç aynı zamanda Kutsal Roma imparatorluğunu da simgelemektedir. (Teksoy, 2001: 526)

"Âdem" diye mirlldaniyordu hepsi;

Sonra halka oldular yaprağı, çiçeği

Kalmamış bir ă̆acın çevresinde.

Öyle genişliyordu ki gövde, ă̆aç yükseldikçe,

Büyük ağaçlara alışık Hintliler bile

Şaşırabilirdi bu ağacı görünce.

Âraf, XXXII, 37-43 
Dante arş-1 âlâya çıktığında devasa büyüklükte binden fazla basamakla içine inilen beyaz bir gül görür, basamaklarında melekler ve kutlular vardır. Ve etrafını gözleri kör eden bir ışık sarmıştır. Bundan sonrasında Beatrice yanından ayrılarak o basamaklardaki yerini alır. Palacios'un, Dante'nin İbn Arabî'den aldığını iddia ettiği ortak motiflerden biri olarak öne sürdüğü geometrik şekillerden biri de binlerce basamağa sahip olan bu gül tasviridir. Ancak Arabî eserinde gül olarak bahsetmez (Palacios, 2015: 207-209).

Böyle büyük bir ışık içerdiğine

Göre en alt basamağı, çok geniş olmalıydı

Bu gülün uç yapraklar!!

Gözlerim gülün eninde, yüksekliğinde

Oyalanmiyordu, bu sevincin niteliğini

Niceliğini kucaklıyordu.

Cennet, XXX, 115-120

İsâ'nın kanını dökerek evlendiği

Kutsal erleri, beyaz bir gül gibi

Görünüyordu gözlerime;

Ötekiler ise, kimi kez çiçeklere,

Kimi kez emeklerinin bala dönüştü̆̆̈̈ yere

Konan bir arı sürüsü gibi uçarken,

Cennet, XXXI, 1-6

\section{Cennet tasviri}

Cennet'e yükselirken gök katlarından çıktığını anlatan Hz. Muhammed feleklerden çıkıp sidretü'l-müntehâya geldikten sonra öncelikle, ikisi görünmeyen, ikisi görünür dört nehir tarafından sulanan - ki bunların görünenleri yeryüzündeki Nil ve Furat nehirleridir-devasa sidr ağacını ve onun gölgelik yaptığı köşklerden ve saraylardan bahseder. Cennet aydınlık, yeşil, kokusu ve renkleri muhteşem olan çiçeklerle ve meyve ağaçlarıyla bezenmiş bir bahçedir.

Dante' nin cenneti ise dokuzuncu katta bulunan devasa beyaz bir güldür. Önceki sekiz katta cennetin katmanlarını oluşturur ancak o katlarda genellikle günahlarından arınmış, dünyada iyi ve dindar olarak yaşamış Yahudi ve Hristiyanlar bulunmaktadır. Dokuzuncu kat ise tam anlamıla cennetin en üst bölgesini oluşturan kattır. Dante, cenneti anlatırken yine Eski Ahit'te tasvir edilen cenneti örnek almıştır.

\section{Tanrı ile buluşma:}

Hz. Muhammed gökyüzünün dokuzuncu katında Allah ile görüştüğünü anlatır. Ancak oraya Cebraîl çıkamamıştır ve O yalnız çıkmıştır.

Dante ise Tanrı'nın onuncu katta olduğunu yazar, kendisi ve rehberi Aziz Bernard dokuzuncu kattan daha ileri gidememiş oradan onuncu kattaki sonsuz ışı̆̆ seyretmişlerdir. 
12. Rehberler:

Her iki yolculukta hem Peygambere hem de Dante'ye yol gösteren, açıklama yapan uhrevî âlemde yaşayan rehberler kılavuzluk etmektedir. Hz. Muhammed'in rehberi başlangıçtan itibaren Cebrâil'dir. Ancak sekizinci kat göğe geldikten sonra Cebrâil daha ileriye gidemez. Hz. Muhammed oradan arş-1 âlâya tek başına çıkar.

Dante' nin Cehennem ve Araf'taki rehberi Virgilius'tur. Cennetteki klavuzu olan Beatrice onu Âraf'ın son katında alıp Cennet'in sekizinci katına kadar çıkarmıştır. Ancak oradan sonra en üst katta bulunan kendi yerine geçmiştir ve bundan sonrasında Dante' ye Fransa'da Claivaux manastırının baş keşişi ermiş Bernard eşlik etmeye başlamıştır. Mi'râcın aksine en üst kata çıkamayan Dante olmuştur ancak bulunduğu yerden beyaz bir gül şeklinde tasvir ettiği arşın tamamını seyredebilmiştir.

\section{Değerlendirme ve sonuç:}

1- Mi'râc hadisesi hemen hemen bütün inanç sistemlerinde karışımıza çıkan bir olgudur. Bu metafizik yolculuğa çıkan insanlar rastgele seçilmiş insanlar değildir, başta peygamberler olmak üzere, veliler, ermişler, din uluları gibi mensubu olduğu inanç sisteminde saygın, güvenilir ve inanılan kişiler olmuştur.

2- Hz. Muhammed'in mi'râcı Kur'an'da ayetlerle tasdik edilmiştir ancak yolculuğun detaylarını hadis rivayetlerinden öğreniyoruz. Edebî bir tür olarak mi'râciyeler, şairlerin belagatini ve hem astronomi hem de din bilgilerini gösterdikleri yeteneklerini en iyi şekilde sergiledikleri şiirler olarak karşımıza çıkmaktadır. Hz. Muhammed'in Mescid-i Haram'dan alınarak Mescid-i Aksa'ya götürüldüğünün kesin olması bize bilimsel olarak ta zamanda yolculuk yapılabileceğini ispat etmektedir. Binitin adının Burak (şimşek) olması bile 1şık hızı ile insanların bu tür yolculuklara çıkabileceğine bir işaret olabilir. Konu ile ilgili araştırma yapan fizik bilginlerinin böyle bir buluşu gerçekleştirmeleri şaşırtıcı olmaz.

3- Dante'nin astral yolculuğunu incelediğimizde ise bize Hz. Muhammed'in mi'râcından çok, bir mutasavvıfın yolculuğuna benzer bir içsel yolculuk olarak değerlendirebiliriz. Öncelikle Dante'nin bu yolculuğu 7 gün sürmüştür, arada uyuduğundan bahseder, bazı sahnelerin etkisiyle bayılır. Güneşin doğuşu, gecenin inmesi, şafak vakti gibi zaman belirten terimler bize yolculukla ilgili bazı ipuçları vermektedir. Dante'nin hayatı ve mensubu olduğu ezoterik tarikat dikkate alındığında eserini daha farklı bir bakış açısıyla değerlendirmek gerekiyor.

Sizler ki akıllı kişilersiniz,

Bu garip dizelerin bir tül gerisinde gizlediğ $i$

Benzetmeyi anlayabilirsiniz.

Cehennem, IX/61-63

Convito (Şölen) adlı eserinde ise bu konuyu daha açık bir şekilde söyler ve bütün metinlerde dört anlam olduğunu ve bu anlamların birbirine zıt olmadığını bilakis 
tamamlayıcı olduğunu anlatır. Tapınak Şövalyesi ve onun bir kolu olan Fede Santa'nın başkanlarından biri olması nedeniyle Dante' nin diğer eserlerinde olduğu gibi İlahi Komedya' yı da içinde barındırdığı sembollerle birlikte okumak gerekiyor. Dante'nin sembolizmi farklı çalışmalara konu olmuştur. Özellikle René Guénon, konuyla ilgili eserinde Dante'nin İlahi Komedya'la kendi inisiyesini (erginlenme) tamamlamış olduğundan bahseder ve şöyle bir ekleme yapar: “Cehennem, profan âlemi temsil etmektedir; Araf, inisiyatik tecrübeleri içermektedir; Cennet (Semâ, Ciel) ise kendilerinde en üst seviyede akıl ile aşkın birleştiği Kâmil insanların ikamet ettiği yerdir..." (Guénon, 2014: 21).

Dante, İlahi Komedya' yı yazarken istifade ettiği başka eserlerin-özellikle Kitab-1 Mukaddes ve Almagest- olduğunu görebiliriz, ancak Palacios'un iddia ettiği gibi cenneti anlattığı bölümde İbn Arabî́den alıntı yaptığını söylemek zorlama bir düşünceden öteye gidemez. Zaten kendisi de Dante'nin Ptolemaios'un (Batlamyus) gezegenlerle ilgili yaptığı bilimsel eseri bildiğini ve konuya oldukça vakıf olduğunu söyler. Bundan sonrası Dante'nin şairlikteki ustalığını göstermesinden başka bir şey değildir.

\section{Kaynakça}

Akar, M. (1980). Miraciyeler. (Doktora tezi). Ankara: Hacettepe Üniversitesi.

And, M. (2012). Minyatürlerle Osmanlı-İslâm Mitologyası. İstanbul: Yapı Kredi Yayınları.

Ayverdi, İ.(2005). Kubbealtı Lugatı, Misalli Büyük Türkçe Sözlük.İstanbul: Kubbealtı Neşriyatı.

Dante, (2001). İlahi Komedya. çev. Rekin Teksoy, İstanbul: Oğlak Yayınları.

El-Fergânî. (2012). Astronominin Özeti ve Göğün Hareketlerinin Esasları. Çev. Yavuz Unat, Ankara: T.C. Kültür ve Turizm Bakanlığı.

Erhat, A. (2001). Mitoloji Sözlüğü. İstanbul: Remzi Kitapevi.

Guénon, R. (2014). Dante ve Ortaçă̆'da Dinî Sembolizm. Çev. İsmail Taşpınar, İstanbul: İnsan Yayınları.

Gündüz, Ş., Sarıkçıŏlu, E., Ünal, Y. (2016). Dinlerde Yükseliş Motifleri ve İslâm'da Miraç. İstanbul: Vadi Yayınları.

İbn Arabî. (2015). Fütuhât-ı Mekkiye, Ahiret Hayatı Cennet ve Cehennem. Çev. Ekrem Demirli, İstanbul: Litera Yayıncilık.

İsmail Hakkı Bursevî. (2007). Mi'râciye. (Haz. İrfan Poyraz). Bursa: Sır

Leonhard, K. (2012). Dante Alighteri. (Çev. E. Zehra Kandemir Mehmet Kandemir), İstanbul: Şule Yayınları.

Palacios, M.A. (2015). Dante ve İslâm. (Çev.Güneş Ayas), İstanbul: Okyanus Yayınevi.

Rapisardo, S. (2017). “La Escatologia musulmana di Asin palacios nella culturaitaliana contemporanea. Una ricezione ideologica?" 15-16 Nisan 2005, Udine Universitesi, (Çev. Kerim Y1lmaz) 
Doğan, M.N. (2002). Şeyh Galib, Hüsn ü Aşk, Metin, Nesre Çeviri, Notlar ve Açıklamalar. İstanbul: Ötüken Yayınevi.

TDK. (2011). Türkçe Sözlük. Ankara: Türk Dil kurumu.

Uludağ, S. (2002). Tasavvuf Terimleri Sözlü̆̆̈̈. İstanbul: Kabalcı Yayınevi.

Vergilius. (2010). Aeneas. (Çev. İsmet Zeki Eyuboğlu), İstanbul: Payel Yayınevi. 